\title{
The State of River Transportation after the Development of Land Transport in East Sumatera 1900-1942
}

\author{
Edi Sumarno $^{1}$, Nina Karina ${ }^{1}$, Junita Setiana Ginting ${ }^{1}$, Handoko ${ }^{1}$ \\ ${ }^{1}$ University of North Sumatera (USU), Indonesia \\ edisumarno64@gmail.com
}

\begin{abstract}
The ports' sites on the river bank were closely related to the river, as the primary and easy means of transportation. Through rivers, the crops from upstream were brought to downstream to be traded and exported abroad, especially to Penang. On the other hand, it was also through the river that the goods were imported from downstream to upstream. In other words, with the absence of land transport, the rivers became very dominant. However, after the presence of plantations, the abundant crops required a more efficient and effective transportation, therefore, the development of land transport, for instance railroad and highway, were paramount. The construction of land transportation facilities certainly had an impact on river transportation. The impact was that river transportation was increasingly abandoned because it was ineffective and inefficient. However, there were several rivers that remained became the most important means of transportation.
\end{abstract}

Keywords : river; transportation; East Sumatera

\section{Introduction}

Before plantations were developed, rivers were the main means of transportation. They were not solely used to transporting people but also the commodities around the river. At that time, the river really was economically used by both the locals and newcomers. There have been many changes in East Sumatra when the economic expansion of plantations began to occur since the last four decades of the $19^{\text {th }}$ century. The expansion had changed the face of East Sumatra from wilderness to plantation area which made this area the most developed area outside Java and later became known as het dollar landsch (land of dollars). These changes were very influential on the life patterns of the local people, including the transportation sector. River transportation as the main means had suffered a setback along with the construction of land transports, specifically roads and railways. The implications of these changes were also very influential on the port as a center of economic, governmental and cultural activity of the local people. The port as a traditional city then suffered a setback due to the construction of highways and railway lines. This was due to the economic activity had shifted from river to land; therefore the traditional ports were relatively less needed.

The ports' sites on the river bank were closely related to the river, as the primary and easy means of transportation. Through rivers, the crops from upstream were brought to downstream to be traded and exported abroad, especially to Penang. On the other hand, it was also through the river that the goods were imported from downstream to upstream. In other words, with the absence of land transport, the rivers became very dominant. Those who hold the hegemony over the river would control the economic benefits and power. The Malay's dominances in East Sumatra were initially formed because of their hegemony over the river, by which the authorities took advantage of export-import excise, trade monopolies, and even the transportation business. This paper will discuss how the states of the river are before the presence of land transport, why the development of land transport is needed and how the existence of the river after that. 


\section{Methodology}

The technique of collecting primary and secondary data was conducted through observation or direct survey to the object of research while the supporting data were gathered from libraries and institutions, for instance National Archive of Indonesia, National Library of Indonesia, Tengku Lukman Sinar Library; this step was carried out to collect archives, books, publications / magazines and others related to rivers and transportations in East Sumatra. The supporting data were obtained from direct visits or field observations by visiting the rivers in East Sumatra. After the data collection was complete, the next step was to verify the data that had been obtained and constructed it into a complete writing.

\section{Discussion}

\subsection{River as a Means of Transportation in East Sumatera}

The term 'city' was unknown before the influence of the Dutch colonial government in East Sumatra at the end of the 19th century. If the city can be simply defined as an area where the center of governmental, economic and cultural activities takes place, then the city at that time was a port. The port at that time was a place where Malay rulers lived and governed, the center of economic and cultural activity.

For technical purposes, the term "port city" will be added to the word "traditional" so that it becomes a "traditional port city". There were many "traditional port cities" in East Sumatra, namely Tanjung Pura in Langkat Sultanate, Labuhan in Deli Sultanate, Rantau Panjang in Serdang Sultanate, Tanjung Beringin in Bedagai Kingdom, Bandar Khalifah in Padang Kingdom, Tanjung Balai in Asahan Sultanate, and Siak Sri Indrapura in Siak Sultanate. Generally, they were located on the banks of rivers, both large and small. Thus, Tanjung Pura was located on the Langkat River, Labuhan on Deli River, Rantau Panjang on Serdang River, Tanjung Beringin on Bedagai River, Bandar Khalifah on Padang River, Tanjung Balai on Asahan River, and Siak Sri Indrapura on Siak River.

Deli River was the most important river in Deli; therefore, many people used it as a means of transportation. Apart from functioning as a means of transportation, many people built their houses close to the river and carried out their agricultural activities there. Relations with other countries, such as trade relations were also carried out through this river lane. ${ }^{1}$ Through Deli River, the relation between England and Deli was created which began with Anderson's visit. Anderson sailed to the upstream of the river, an area that had not been visited by other westerners. The shallow conditions of the beach forced Anderson to anchor off the coast and continue the journey by small boat, enter the rivers and walk along the river banks visiting village after village. On January 16, 1823, Anderson landed in Deli. On his observation, Anderson noted that there were many people who were proficient at making ships and boats in Deli. ${ }^{2}$

Not only had Anderson visited Deli, he also visited Sultan Kejeruan Muda in Langkat, Sri Sultan Ahmat in Bulu China, Sultan Agung from Serdang, treasurer in Batubara, Yang di

\footnotetext{
${ }^{1}$ Edi Sumarno, "Pertanian Karet Rakyat Sumatera Timur (1863-1942)" unpublished Tesis S2, Yogyakarta: Universitas Gajah Mada, 1998, pg. 52-53.

${ }^{2}$ John Anderson, Acheen and the Port on the North and East Coast Sumatra, London: Wm. H. Allen \& Co. Leadenhall Street, 1840, pg. 178-179
} 
Pertuan Asahan, and Sultan Siak. All of these sultanates or regions still used the river as the main transportation. Although roads had been built, the role of the river as a means of transportation was still paramount. The rivers in the south, for example, were wide and deep, therefore many boats or canoes were transporting commodity products back and forth from the inland which were then bartered in the downstream. Asahan River, Silau River, Bilah River, Kualuh River and Barumun River were wide, deep, and crowded rivers at that time. Many residents' houses faced the rivers. Apart from being a means of transportation, the rivers were also used for daily activities such as bathing, washing and so on. ${ }^{3}$

\subsection{The Development of Land Transport in East Sumatera}

Boat transportation became an obstacle for plantations industry because the amounts of goods transported were relatively small and it spent a lot of time and money. This was certainly inefficient for the plantation party, therefore the Onderneming party decided to build a highway at the end of the 19th century. The construction of the highway, especially in the cultuurgebied, was spearheaded by the onderneming for their own interests. These roads were split in the middle of a plantation to facilitate crops planting and transportation. One of the onderneming parties that built their own highway was the Deli Maatschappij. In the 1880s, they built a $10 \mathrm{KM}$ road between Medan and Sunggal and another $20 \mathrm{KM}$ road from Lubuk Pakam to Bangun Purba.

Road construction was then continued by the government. Until 1918, the government had built a main road of more than $500 \mathrm{KM}$ connecting the important cities in the cultuurgebied. The lines constructed were $107 \mathrm{KM}$ road from Medan to Pangkalan Berandan passing through Binjai and Tanjung Pura, $81 \mathrm{KM}$ road from Medan to Tebing Tinggi, then another $115 \mathrm{KM}$ from Tebing Tinggi to Tanjung Balai passing through the Kualuh border in Asahan, $22 \mathrm{KM}$ road from Medan to Belawan, $79 \mathrm{KM}$ road Medan to Kabanjahe, $92 \mathrm{KM}$ road from Lubuk Pakam in Serdang to Seribu Dolok in Simalungun, 53 KM road Tebing Tinggi to Pematang Siantar, 46.5 KM road from Pematang Siantar to Parapat, and Kabanjahe passing through Seribu Dolok in Simalungun to Lake Toba. In addition, the connecting road between the cultuurgebied and other regions was also built, such as from Kabanjahe to Kotacane, and from Parapat to Tapanuli. ${ }^{4}$

These constructions assuredly expedited the flow of goods; especially the plantations in Afdeling Deli en Sedang were no longer facing problems in transporting their plantation commodities which were then exported through Belawan Port. These constructions accelerated the activities in Belawan for the flow of goods transported was getting increased. It indicated that with the construction of highways connecting the land did not hamper the activities in the ports because generally when the Dutch colonial government built highways, river port cities had already suffered setbacks.

The Dutch colonial government through the private sector not only built the highways, but also railways. Progress and development of transportation made people constantly try to find ways to organize a fast and smooth transportation. The government finally developed railways which was able to ease the burden in its driving force so that it could transport more

\footnotetext{
${ }^{3}$ John Anderson, Mission to East Coast of Sumatera in 1823, Kuala Lumpur/Singapore/New York/London: Oxford University Press,1971, pg. 18-20.

${ }^{4}$ R. Broersma, Oostkust van Sumatra: De Ontwikkeling van het Gewest, deel II, The Hague: Charles Dixon Deventer, 1922, pg. 263.
} 
plantation commodities. This policy made the railway company immediately involved itself in building transportation facilities in the plantation area. ${ }^{5}$

The East Sumatra region was well-known after the government established this region as agricultural producers whose commodities were then exported to Europe and America. Trains played a role in terms of transportation, especially from the hinterland area of the plantation until goods could be transferred to ports to be immediately transported by ship. This policy was an answer to the needs of the plantation sector for transportation. The railroad network, which was built in the late 19th century, aimed to serve a rapidly growing colonial export and import economy. ${ }^{6}$ The realization of the railroad network construction in East Sumatra was initially focused on three areas covering Deli, Serdang and Selesei regions. These areas were very compatible for railroad network due to the flat land conditions and close distance to Medan. For 37 years, starting from 1886 to 1937, the Deli Spoorweg Maatschappij (DSM) had built a railroad network of 553,254 KM. ${ }^{7}$ The constructions had a positive impact on economic development on the plantation. This positive impact could be seen with a large volume of goods capacity where they could be transported all at once that would eventually save a lot of operational costs. However, they also had a negative impact, especially on the development of river transportation which prior to the presence of the railroad was the main and important facility in East Sumatra.

The construction of highways and railway network to the inland region and its urgency in supporting the growth of the plantation industry had resulted in the role of traditional ports which at the same time were the traditional centers of power to change. Only the ports in the afdeling Bengkalis and Asahan still survived. The other ports suffered a setback along with the rapid progress of the "modern" port Belawan as the main port in East Sumatra. This happened because many export activities were carried out through this port with supporting facilities like highways and railways. Along with that, many import activities were also carried out in the same port from which the goods were later distributed to many regions in East Sumatra. ${ }^{8}$

\subsection{The State of Rivers after the Development of Land Transport}

The rapid development of plantations in East Sumatra had an impact on the development of land transport. The construction of land transport was the plantation party's effort to get the plantation crops transported effectively and efficiently. To that end, the plantation urged the Dutch colonial government in East Sumatra to build cross-government roads that connected regions in East Sumatra. The roads were necessary due to the fact that the roads built by the plantation party were only limited to roads connected one plantation to another.

The plantation party's demands were fulfilled by the government; the construction of roads from inland areas was followed by the construction of a large highway that ran parallel to the coast from the border of Aceh to Rantau Parapat. These roads stretched from northsouth to east-west and from the mountains to the coast. However, until the end of 1928, several large onderneming still did not have access to roads built by the government, most of

\footnotetext{
${ }^{5}$ Indera, "Pertumbuhan dan Perkembangan Deli Spoorweg Maatschappij, 1883-1940" Tesis S-2, unpublished, Depok: Universitas Indonesia, 1996, pg. 52.

${ }^{6}$ Ibid., pg. 53.

${ }^{7}$ Ibid., pg. 90 .

${ }^{8}$ Ibid., pg. 2-3.
} 
which were located in the southern part of East Sumatra. They still used canoes in transporting their plantation commodities through Labuhan Bilik Port, close to the estuary of Bilah River and Negerilama. ${ }^{9}$

Not only the Bilah and Negerilama Rivers, rivers were also still used on several areas in the southern part of East Sumatra. Merbau River for example, to support the transport of plantation products, the colonial government through public works services (BOW) built docks, stockpiles and waiting rooms with a budget of $f 9,855$. Docks were built on the banks of the Merbau River to connect tributaries such as Sipare-pare, Pangkailan and Lubuk Rampah. The government always kept the rivers deep enough to be passed by canoes and ships with large tonnage by placing a bagermolen (dredging machine / sludge suction) on each river base. ${ }^{10}$

The statements above indicate that the role of the river was still maintained even though the construction of land transport continued to develop. With the government's concern to continue exploiting the river as a means of transportation, the existence of the river also continued to thrive. The reason why the river was still used especially in the southern region of East Sumatra for the transport of plantation commodities was because the river was wide and deep. The state of the rivers were quite different in the northern regions of East Sumatra such as Serdang, Deli and Langkat where they were not as wide and they continued to suffer from siltation and constriction so that it was not possible to continue using them as a means of transportation.

\section{Conclusions}

The development of the plantation industry had both positive and negative impacts. The positive impact was the construction of more adequate, effective and efficient transportation facilities. In addition, with the construction of highways and railways network, the commodities were evenly distributed which led to the creation of new economic embryos. Nevertheless, the development of land transport also had a negative impact, especially in term of the role of the river as a means of transportation that was considered ineffective and inefficient. However, the role of the river was still maintained, especially in the southern part of East Sumatra even though the development of land transport continued to grow. Rivers in the southern region kept on developing for the government was building supporting facilities and infrastructure to transport the plantation commodities.

\section{References}

Anderson, John, 1840, Acheen and the Port on the North and East Coast Sumatra, London: Wm. H. Allen \& Co. Leadenhall Street.

Anderson, John, 1971, Mission to East Coast of Sumatera in 1823, Kuala Lumpur/Singapore/New York/London: Oxford University Press.

\footnotetext{
${ }^{9}$ Karl J. Pelzer, Toean Keboen dan Petani: Politik Kolonial dan Perjuangan Agraria di Sumatera Timur 18631947, (trans. J. Rumbo) Jakarta: Sinar Harapan Publisher, 1985, pg. 87-88.

${ }^{10}$ ANRI, "Rapport over het onderzoek naar de bevaarbaarheid van de Bila Rivier en de Merbau Rivier in de Residentie Oostkust van Sumatra", Arsip Inventaris BOW No. 2656.
} 
ANRI, "Rapport over het onderzoek naar de bevaarbaarheid van de Bila Rivier en de Merbau Rivier in de Residentie Oostkust van Sumatra", Arsip Inventaris BOW No. 2656.

Broersma, R.,1992, Oostkust van Sumatra: De Ontwikkeling van het Gewest, deel II, The Hague: Charles Dixon Deventer.

Indera, 1996, "Pertumbuhan dan Perkembangan Deli Spoorweg Maatschappij, 1883-1940" Tesis $S$-2, unpublished, Depok: Universitas Indonesia.

Pelzer, Karl J., 1985,Toean Keboen dan Petani: Politik Kolonial dan Perjuangan Agraria di Sumatera Timur 1863-1947, (terj. J. Rumbo) Jakarta: Sinar Harapan Publisher.

Stoler, Ann Laura, 2005,Kapitalisme dan Konfrontasi di Sabuk Perkebunan Sumatera (1870 1979), Yogyakarta: Karsa.

Sumarno, Edi, 1998, "Pertanian Karet Rakyat Sumatera Timur (1863-1942)" Unpublished Tesis S2, Yogyakarta: Universitas Gajah Mada.

Sumarno, Edi, "Mundurnya Kota Pelabuhan Tradisional di Sumatera Timur pada Periode Kolonial" dalam Historisme Ed. NO.22/Year XI/August 2006.

Volker, T.,1918, Van Oerbosch Tot Cultuurgebied: Een Schetsvan de Beteekenis van de Tabak, de Andere Cultures, en de Industrie ter Oostkust van Sumatra, Medan, De Deli Planters Vereeniging. 